\title{
The Crisis of Public Transport in India: Overwhelming Needs but Limited Resources
}

\author{
John Pucher and Nisha Korattyswaroopam, Rutgers University \\ Neenu Ittyerah, Indian Railways, Chennai, India
}

\begin{abstract}
The rapid growth of India's urban population has put enormous strains on all transport systems. Burgeoning travel demand far exceeds the limited supply of transport infrastructure and services. Public transport, in particular, has been completely overwhelmed. Most bus and train services are overcrowded, undependable, slow, inconvenient, uncoordinated, and dangerous. Moreover, the public ownership and operation of most public transport services has greatly reduced productivity and inflated costs. India's cities desperately need improved and expanded public transport service. Unfortunately, meager government financial assistance and the complete lack of any supportive policies, such as traffic priority for buses, place public transport in an almost impossible situation.
\end{abstract}

\section{Introduction}

Public transport faces severe problems in almost all countries of the developing world, although the situation varies from one country to another, and even from one city to another (Vasconcellos 2001). Perhaps most important, the lack of financial resources prevents necessary investments in maintaining and upgrading 
existing bus and rail systems and building new ones. Likewise, many advanced technologies long available in Western Europe are simply not affordable in most developing countries. Public transport systems in the Third World are plagued by chronic corruption and inefficiency, overcrowded and undependable service, congested roadways that slow down buses, and an operating environment that is often chaotic and completely uncoordinated.

Those problems of public transport occur within the broader context of daunting urban transport problems in general. Air pollution, noise, congestion, and traffic fatality levels are often much more severe than those of developed countries. One might expect the much lower incomes in developing countries to assure a huge potential market of public transport riders. In fact, many city residents are so poor that they cannot afford even low fares, and routes are not designed to serve the poor at any rate. Thus, the poor in developing countries suffer even more than those in the Western World from low levels of mobility and accessibility, especially to jobs.

In many respects, the situation in India is typical of other developing countries. The most important commonality is India's low per-capita income-only US $\$ 2,540$ in 2002, less than a tenth of the average incomes of countries in North America and Western Europe (Central Intelligence Agency 2002). With 23 percent of its urban population living in poverty, India has been forced to keep its public transport fares extremely low. That has sharply restricted the operating revenues of all public transport systems, making it difficult to afford even routine maintenance and vehicle replacement, let alone system modernization and expansion.

Poverty is not only a problem at the individual level, but also in the public sector, with cities and transport systems desperately lacking the necessary financial resources for investment in infrastructure, vehicles, new technologies, and fare subsidies. The financial problems stemming from India's low per-capita income are probably the most important challenges facing Indian public transport, but there are many others as well: inefficiency, roadway congestion, traffic accidents, lack of planning, overcrowding, noise, and total lack of coordination of any kind.

\section{Trends in Population and Land Use}

The rapid growth of India's urban population - as in other developing countries $3 / 4$ has generated an enormous need for efficient public transport services to carry high volumes of passengers through dense, congested urban areas. By 2001 over 285 
million Indians lived in cities, more than in all North American cities combined (Office of the Registrar General of India 2001). There has been especially rapid growth of the very largest metropolitan areas such as Mumbai (Bombay), Kolkata (Calcutta), and Delhi, which now exceed 10 million residents each. Chennai (Madras), Hyderabad, Ahmedabad, and Bangalore each have more than 5 million residents. And 35 metropolitan areas have populations exceeding 1 million, almost twice as many as in 1991. Since large cities are far more dependent on public transport than small cities, the need for public transport services has increased faster than overall population growth.

Moreover, the lack of effective planning and land-use controls has resulted in rampant sprawled development extending rapidly in all directions, far beyond old city boundaries into the distant countryside. That also has greatly increased the number and length of trips for most Indians, including those by public transport.

Most public policies in India actually encourage sprawl. In an explicit attempt to decongest city centers, government regulations limit the ratio of floor areas to land areas for buildings in the center, and thus restrict the heights of buildings and density of development in the center. For example, the so-called "floor space index" in sampled city centers in India was only 1.6, compared to indices ranging from 5 to 15 in other Asian city centers (Bertaud 2002; Padam and Singh 2001). By contrast, government regulations permit higher floor space/land area ratios in suburban developments, yet more inducement for firms to decentralize. Indeed, local governments even advertise the less stringent regulations in the suburbs to promote more development there. Such land-use policies obviously discourage development in the center and force both firms and residences to seek locations on the suburban fringe. Moreover, local governments have permitted scattered commercial and residential development in outlying areas without the necessary infrastructure such as roads, utilities, hospitals, shopping, and schools. That generates long trips between residences and almost all other trip destinations.

Just as in North America, most new commercial development is in the distant suburbs. For example, Tidal Park is a software center on the outskirts of Chennai; Gurgaon is a large new industrial area outside Delhi; and Pimpri-Chinchwad is a similar center outside of Pune (Bertaud 2002). Similarly, Bangalore is planning several technology parks on its fringe as well as several circumferential highways in the suburbs, both of which will induce further decentralization. In most cases, there is inadequate infrastructure to serve these new suburban developments and the residences locating around them. Ramachandran (1989) characterizes Indian sub- 
urbs as an "uncontrolled mix of industrial development, dumps and obnoxious uses," with the "extension of urban settlement causing conditions in the overtaken villages to deteriorate, both physically and socially." The leap-frog development typical of suburban sprawl tends to follow major highways out of Indian cities to the distance countryside.

There are important consequences of such low-density, sprawled decentralization for public transport. Just as in North America and Europe, it generates trips that are less focused in well-traveled corridors and thus more difficult for public transport to serve. In India, it has led to rapid growth in car and motorcycle ownership and use and thus increasingly congested roadways that slow down buses, increase bus operating costs, and further discourage public transport use.

\section{Trends in Public Transport}

The best statistics for public transport in India are for suburban rail, because it is centrally owned and operated by Indian Railways. As shown in Figure 1, suburban rail usage has sharply increased over the past five decades, with a 14-fold growth in passenger km of travel (Indian Railways 2001). There are no comprehensive national statistics on bus service supply, let alone the number of riders, but the fragmented statistics for individual cities suggest substantial growth. For example, in the 10 years from 1990 to 2000, there was an 86 percent increase in the size of Mumbai's bus fleet, and a 54 percent increase in Chennai's bus fleet. While the size of Delhi's public bus fleet actually fell, the number of private buses rose by almost twice as much, yielding a net 28 percent increase (Association of State Road Transport Undertakings 2002). 


\section{Figure 1. Growth in Suburban Rail Travel in Indian Cities 1951 to 2001 (in millions of passenger km)}



Source: Indian Railways 2002

Buses carry more than 90 percent of public transport in Indian cities. Indeed, most Indian cities have no rail transport at all and rely instead on a combination of buses, minivans, auto rickshaws, cycle rickshaws, and taxis. Even in most of the largest cities, rail transport carries less than a third of public transport passengers. The only exception is Mumbai, which has India's most extensive suburban rail network, carrying more than 5 million passengers a day3/458 percent of total public transport passengers in the region ( $v .42 \%$ by bus) and 80 percent of total passenger $\mathrm{km}$ (v. 20\% by bus) (Brihanmumbai Electric Supply and Transport 2003; Indian Railways 2002).

In general, the larger the city size, the higher the percentage of urban trips served by public transport in India: 30 percent in cities with population between 1 and 2 million, 42 percent for cities with populations between 2 and 5 million, and 63 percent for cities with populations over 5 million (Sreedharan 2003). Thus, the especially rapid growth of large cities suggests a further rise in future demands for public transport in India.

As shown by Figure 2, however, there is substantial variation among cities of the same size category. Almost 80 percent of all trips in Kolkata are by some form of 
public transport, compared to about 60 percent in Mumbai, and 42 percent in both Chennai and Delhi. Differences in land use and roadway supply explain some of the variation. Delhi and Chennai are lower density, more polycentric, and more spread out than Mumbai and Kolkata. Delhi also has a particularly extensive roadway network, while the supply of roadways in other large Indian cities is much more limited. For example, 21 percent of Delhi's total land area is devoted to roads, compared to only 11 percent in Mumbai and 5 percent in Kolkata. Mumbai and Kolkata also have more restricted geographies, since both are situated on peninsulas that channel travel and land-use development in only a few directions. Such focused travel corridors especially encourage suburban rail use, as in Mumbai. Delhi has no such geographic restrictions and sprawls out in all directions. Thus, Delhi currently relies primarily on auto rickshaws, motorcycles, taxis, and private cars to serve the multidestinational, less focused travel patterns of its residents.

\section{Figure 2. Percent Distribution of Urban Trips by Means of Travel for Selected Indian Cities, 2002}



Sources: Pendakur 2002 and World Bank 2002 
The range of public transport services available also varies considerably, even among the largest categories of cities. Only Mumbai, Kolkata, and Chennai have extensive suburban rail services. Delhi has limited suburban rail services. Until recently, Kolkata had India's only underground metro system (16.5 route $\mathrm{km}$ ), but Delhi is currently constructing a far more extensive metro (62.5 route km) (Delhi Metro Rail Corporation 2003a). Chennai has a hybrid surface and elevated metro, designated as Mass Rapid Transport System, which currently extends $8.6 \mathrm{~km}$ and is being expanded by another 11.2 km (Southern Railway 2003). Finally, Kolkata has India's only remaining tram system, a $68-\mathrm{km}$ double-track network of old, seriously deteriorating tracks and vehicles.

As noted previously, buses account for most public transport services, even in these large cities, and for virtually all public transport services in cities with less than 5 million residents. Moreover, all Indian cities feature large numbers of auto rickshaws (3-wheeled motorized, minicars), taxis, and cycle rickshaws (human-powered carts).

\section{Problems and Challenges}

The sharply rising demands for public transport have overwhelmed the existing public transport systems in India. Trains and buses in most cities are dangerously overcrowded. On suburban rail lines in Mumbai, peak-hour trains must carry more than twice their maximum design capacity, leading to inhuman traveling conditions, with so-called "super dense crush loads" of 14 to 16 standing passengers per square meter of floor space (Varshneya, Jain, and Sahai 2002; Ministry of Railways 2002)! On peak-hour trains, many passengers are forced to hang out doors and windows or to ride between train cars or even hang on the outsides of cars. Suburban trains and stations seem hopelessly overcrowded and desperately need expanded capacity.

Buses in Indian cities are doubly disadvantaged by congested conditions. Buses themselves are seriously overcrowded, with some passengers forced to ride on the outsides of vehicles. In addition, however, buses must negotiate extremely congested, narrow streets, with no separate rights-of-way at all, having to fight with a mixed array of animal-drawn carts, minivans, cars, taxis, motorized two-wheelers, auto rickshaws, pedestrians, cyclists, and street vendors. Severe roadway congestion has slowed down most buses to a crawl during much of the day3/4as slow as 6 to $10 \mathrm{~km}$ per hour in many large cities (Gakenheimer and Zegras 2003). 
These congested conditions in public transport vehicles, stations, and rights-ofway not only slow down travel but make it outright dangerous. Tens of thousands of public transport passengers are killed or injured every year in accidents. Many buses and trams do not even have doors and windows that can be closed, and that only encourages passengers to ride by protruding from inside the vehicle or by hanging on from outside. Clearly, riding on the roofs or sides of buses and trains is inherently unsafe and results directly from the severe undercapacity of public transport systems in India. Slow, uncomfortable, undependable, and unsafe conditions in the early 1990s led to riots of passengers protesting these inhumane conditions, forcing some of the service expansion efforts described later in this article (Acharya 2000).

One consequence of insufficient service quantity and terrible service quality is that public transport has been losing market share in many cities. Dissatisfied public transport passengers are increasingly turning to the private car, and even more dramatically, to the relatively low-cost motorized two-wheelers, which have experienced a boom in ownership and use in the past 10 years. As shown in Figure 3, the total number of private cars and motorized two-wheelers increased roughly four times faster than the number of buses over recent decades (World Bank 2002; Ministry of Road Transport and Highways 2003). For much of the Indian middle class, the motorcycle offers an affordable, far more flexible, convenient, faster, and more dependable way of getting around than public transport. For affluent Indians, the private car offers an even higher level of comfort and greater prestige, although it is more likely than two-wheelers to be slowed down by roadway congestion.

The deteriorating quality of public transport service reinforces the impact of the rapid decentralization of Indian cities. Both trends encourage a shift away from space-saving public transport toward individual motorized transport. That has greatly increased roadway congestion, further reduced travel speeds, and aggravated traffic safety problems. Perhaps because of its separate rights-of-way and thus higher speeds, suburban rail continues to experience strong growth in passenger levels, in spite of crowded vehicles and stations and undependable service. By comparison, bus systems in some cities have suffered losses of passengers in recent years, as their overcrowded buses get bogged down in slower and slower traffic.

Another crucial problem of Indian transport is inefficiency, lack of productivity, overstaffing, excessively high operating costs, and large subsidy needs. Especially 


\section{Figure 3. Growth of India's Motor Vehicle Fleet by Type of Vehicle 1950-2001 (in thousands of vehicles)}



Source: Ministry of Road Transport and Highways 2003

since the mid-1990s, operating deficits have been rising rapidly. For bus systems in the largest cities, the combined operating deficit quadrupled (Association of State Road Transport 2002b), and for Indian Railways, the annual operating deficit tripled. As shown in Figure 4, most publicly owned bus systems in large cities generally cover about 70 to 90 percent of operating costs, much higher than large public transport systems in Western Europe. The most unprofitable bus system is in Kolkata, which covers only 42 percent of costs through passenger fares, while Delhi (72\%) and Mumbai (80\%) cover about three-fourths of costs. At the high end of the scale, Bangalore (105\%) is actually profitable, and Hyderabad (92\%) almost breaks even. It is notable that both of the publicly owned bus firms in Bangalore and Hyderabad contract many of their services to privately operated companies, which probably explains the better economic performance. 


\section{Figure 4. Proportion of Operating Expenses Covered by Passenger Revenues for Selected Cities in India, 2000-2001}



Source: Association of State Road Transport Undertakings 2002

Clearly, much could be done to improve the efficiency of both bus and rail operations, most of which are publicly owned, operated, and regulated. There are many institutional obstacles to any fundamental changes, including powerful labor unions representing employees, which have blocked changes that would disadvantage them.

\section{Privatization}

One possible solution to many of these problems might be the selective privatization of India's public transport sector. That could be done either through opening up the market to private firms (who would own, manage, operate and finance their own systems) or by having public agencies contract with private firms to operate services on a systemwide basis, for selective routes, or for selected functions (like maintenance). Rail systems have only rarely been privatized anywhere in the world (except for certain narrow functions), while there is considerable experience with 
bus privatization. Thus, privatization seems an option only for bus services, but they account for more than 90 percent of India's public transport.

Privatization of public transport in India was strongly encouraged by the World Bank (2002), which accused publicly owned and operated systems of being inefficient and highly unprofitable, providing insufficient and low-quality services, and failing to respond to market demands. Although there were some minor attempts at privatization in the 1980s, the first large-scale privatization of buses occurred in Delhi in 1992, when numerous small, private bus firms entered the market. Unfortunately, the new private operators were not adequately regulated and coordinated, leading to complete chaos. The new private services tortured passengers with lengthy, zig-zag routes, long waiting times, completely unreliable service, extreme overcrowding, unqualified drivers, speeding and reckless driving, fights among competing buses, and even running down passengers waiting at bus stops. Moreover, the private buses were often poorly maintained, unsafe, noisy, and highly polluting, adding to the already severe congestion, safety, and air pollution problems in Delhi.

In the years since 1992, regulations have been strengthened and better enforced. Moreover, the many private bus operators are now much better coordinated than at the outset. Service quality problems still remain, but privatization appears to have brought some substantial economic benefits. In a comparison of public and private bus operators in Delhi, the World Bank found that private bus firms carried twice as many passengers per bus per day (1,584 v. 751), earned twice as much revenue per bus per day (2,700 v. 1,321 Rupees), required less than half the staffing per bus ( 4.6 v. 9.6 employees), cost less than half as much per bus $\mathrm{km}$ ( $7.7 \mathrm{v} .17 .2$ Rupees), and actually made a profit (3.2 Rupees per bus $\mathrm{km}$ ) while the public bus firms ran a loss (11.0 Rupees loss per bus km) (Marwah, Sibal, and Sawant 2001).

These financial comparisons between public and private buses are somewhat exaggerated, since private firms can usually select profitable routes, while public firms are often required to provide unprofitable services on lightly used routes to achieve social objectives and ensure comprehensive coverage to the entire city. Moreover, private bus companies offer their employees much lower wages, less job security, and less generous fringe benefits such as pensions and health insurance. Thus, to some extent, the private bus firms have lower costs due to lower salaries for their workers. 
Kolkata currently has a large number of privately operated buses as well (about 1,800 private v. 1,200 public), and as in Delhi, they have fewer employees per bus, lower costs, and much higher cost coverage through fare revenues than the publicly operated buses. Privatization in Bangalore and Hyderabad has so far been limited to the contracting out of certain routes to private operators, but still with the overall coordination of a public agency.

It appears that privatization does indeed have much potential to improve efficiency, but that it must be accompanied by strict regulations, performance standards, and overall coordination to ensure an integrated network of services. In light of the transport funding crisis in Indian cities, they may have little choice but to seek the cost savings possible with privatization and increased competition.

\section{Funding}

Since passenger revenues do not cover the full costs of operation and capital investment of public transport, government financial assistance is obviously crucial. As owner of Indian Railways, the Central Government must bear whatever operating deficit remains after the substantial cross-subsidies from profitable freight services. In the past, the Central Government also bore most of the costs of capital investment, but in recent years, state governments have financed growing portions of these costs, especially for the expansions and improvements of suburban rail systems in Mumbai, Chennai, Kolkata, and Hyderabad (Ministry of Railways 2002). To encourage more state contributions, Indian Railways now gives priority to projects with up to two-thirds state government funding.

Funding for new and expanded metro rail systems comes from the Central Government as well as state and local governments, but there is no exact formula, and the distribution of contributions varies from case to case. The World Bank, the Japanese Bank for International Cooperation (JBIC), and other international lending agencies have also provided loans for large infrastructure projects. For example, a JBIC loan is funding two-thirds of the capital cost of building the Delhi Metro (Delhi Metro Rail 2003b). Rail system operating deficits, however, are primarily borne by local governments.

Most bus services are still publicly owned and operated by STUs (State Transport Undertakings), whose operating and capital investment costs are covered by a combination of state and local government subsidies, grants, and loans that vary from state to state. 
Significantly, no government level has any dedicated taxes whose proceeds would be automatically earmarked for public transport. Thus, financial support for public transport is tenuous, depending on annual budgetary appropriations. With critical shortages of revenues at every government level, public transport must compete each year with many other urgent needs for public funds. The willingness of the Central and state governments to fund public transport can vary substantially over time, making long-term planning very difficult.

\section{Recent and Planned Improvements}

In spite of severe shortages of both public and private financing for improving public transport, several Indian cities have been trying to provide more and better services to meet burgeoning travel demands. The most extensive improvements are in Mumbai. For example, Indian Railways has already opened two new suburban rail lines and has plans for additional extensions. Several existing lines have been vastly improved by constructing additional tracks (from one to two tracks and from two to four tracks) to permit separation of local and express trains. Moreover, cars have been added to trains, average speeds have increased, and frequency of service has also risen-measures aimed at mitigating the overcrowding problem. By relocating more than 6,000 illegal slum dwellings that encroached on land directly adjacent to railway tracks, Indian Railways increased service dependability, speed, and safety (Mumbai Metropolitan Region Development Authority 2003).

An especially innovative initiative is the planned Sky Bus system, which will feature several lines of express buses on elevated guideways. The initial phase, which extends $8.3 \mathrm{~km}$, scheduled for completion by 2006, should help to relieve the most congested suburban rail and bus routes in the same corridors (Konkan Railway Corporation Ltd. 1999). Finally, the main bus operator in Mumbai (BEST) has already introduced smart cards for fare collection on some premium bus services and also plans to introduce low-floor buses to facilitate travel by passengers with disabilities (Brihanmumbai Electric Supply and Transport 2003).

Delhi has been innovative on at least three different fronts. It has been constructing a new metro system with three lines, but only a small section is currently in service. When completed, it will have $12.5 \mathrm{~km}$ of underground lines and $50 \mathrm{~km}$ of surface or elevated lines. By the year 2005, the Delhi Metro is expected to carry more than two million passengers a day (Delhi Metro Rail Corporation 2003c). Delhi has also been at the forefront of innovations in bus services, both by requir- 
ing a complete switchover to nonpolluting CNG buses and by introducing privatization and increased competition among bus firms to reduce costs. As noted earlier, both of those policy changes caused enormous disruptions in service for several transitional years, but the overall result has been positive.

Kolkata is currently extending its existing $16.5 \mathrm{~km}$ underground metro by another 8.5 km (Metro Railway Kolkata 2003)

Chennai completed the first phase of its Mass Rapid Transit System in 1997, which includes $6 \mathrm{~km}$ of elevated track and $2.6 \mathrm{~km}$ of surface track. Currently, the system is being extended by another $11.1 \mathrm{~km}$, with at least $40 \mathrm{~km}$ of future expansions planned (Southern Railway 2003). The initial phase was disappointing because it was not well coordinated with bus and suburban rail services, but those problems are currently being handled through significant improvements in parking and better connections to bus and suburban rail. Connections are also being improved between three of the suburban rail lines in Chennai, with physical links now possible thanks to gauge conversions for compatibility. Finally, Chennai has plans to introduce privatized, competitive bus services on roughly half its bus routes, following the example of Delhi and the recommendations of the World Bank.

Bangalore had planned a new light rail system, but it has been indefinitely postponed due to a shortage of funds. Instead, a less expensive system of grade-separated busways and high-capacity articulate buses is being considered (Gaur 2002).

The suburban rail services in Hyderabad are being expanded and improved, with a special focus on upgrading station areas and enhancing safety. In addition, transfers between bus and rail services are being facilitated by better coordination between the city bus services and Indian Railways.

\section{Recommended Policy Shifts}

Given the rapid growth of India's largest cities and the desperate need for better and expanded public transport, it is crucial that policies change to improve the entire range of public transport services offered. Unfortunately, the Indian government has been emphasizing instead the need to further develop the nascent automobile industry in India and has actually encouraged more private car ownership and use. Indian cities are simply not equipped to handle increased volumes of private vehicle use. Roadways are already hopelessly congested, with average speeds declining each year. Even for automobile users, it will be important to improve 
public transport, if only to remove some traffic from the streets and thus reduce congestion to manageable levels and increase travel speeds.

Clearly, public transport must be given priority attention to avoid further deterioration of air quality, traffic safety, congestion, and noise in Indian cities. While some improvements can be made even with existing funding levels, most would require massive infusions of new funding for expanded and modernized bus and rail systems. Equally important, state and local governments must give traffic priority to buses, both through special bus lanes and signal priority over private transport.

With more than 90 percent of public transport passengers in Indian cities relying on buses, it is especially important to upgrade bus services through modern, safe vehicles and priority on the congested roadways. The heavy, high-floor buses currently in service in most cities are noisy, polluting, fuel-inefficient, and unsafe. They are built on truck chassis with such high floors that boarding is slow and difficult. Moreover, they have slow acceleration as well as poor fuel economy due to their weight, and are inappropriate to urban use. Many buses do not even have closable windows and doors to protect passengers from the weather and from falling out of the vehicle. It is essential to replace these outdated buses with modern, safe, clean, and fuel-efficient vehicles.

Improving and expanding rail systems is also crucial, since they are insulated from the congestion delays caused by roadway traffic. Unfortunately, they are usually very expensive, and it is not realistic to expect that even most large Indian cities will be able to afford new rail systems. Moreover, for medium and small cities, where public transport services are either nonexistent or very infrequent, as well as slow and crowded, improved bus service is the only feasible option. Private vehicles have a much higher share of total trips in small and medium-sized cities precisely because the bus services there are so inadequate.

Within the current funding limits, it would still be possible to vastly improve the transfer connections between rail and bus lines, as well as to introduce integrated ticketing for all public transport modes. In addition, the privatization and increased competition among bus services already implemented in Delhi and a few other cities might be adopted more widely, as it would increase efficiency and reduce costs. That would, however, have to be accompanied by strict regulation and enforcement of safety and pollution standards combined with overall regionwide coordination of all public transport services. It was the failure to regulate and coor- 
dinate the new private bus operators in Delhi that led to the serious problems of unsafe, overcrowded, unpredictable, and uncoordinated private buses.

The main problem in Indian cities, however, is financial. To some extent, operating revenues of public transport firms could be greatly enhanced by targeting fare subsidies to low-income passengers and raising considerably the fares for the middle and upper classes. As noted earlier, fares on most systems are extremely low3/4and passenger volumes are extremely high $3 / 4$ so that even modest increases might yield substantial revenues for system maintenance, modernization, and expansion. Fares cannot be raised too high, however, even among middle-class riders, since they might then be diverted to private transport modes, which cause the most urban transport problems. Thus, larger subsidies from the public sector will be essential.

Until all levels of government in India devote the necessary funding to expanding and improving public transport, it will remain overcrowded, unsafe, undependable, and unpleasant, thus encouraging ever more Indians to turn instead to the private car and motorcycles, which would lead to even more serious congestion and pollution problems in Indian cities. The ideal source of such funding would be some sort of dedicated gasoline or private motor vehicle tax whose revenues would be devoted specifically to the improvement of urban transport conditions, including better roadways, better bicycling and walking facilities, and above all, better bus and rail services. Many of the world's developed countries have used such dedicated gasoline and motor vehicle taxes for decades to fund their public transport improvements. In India, it would be doubly beneficial. Such a tax would discourage nonessential private car ownership and use. Moreover, the burden of the tax would fall on relatively affluent Indians, so that the overall impact would be quite progressive. The solution to public transport's financing problem in India seems quite clear, but does the Indian government have the political will to implement it? 


\section{References}

Acharya, R. 2000. Indian railways: Where the commuter is king. Japan Railways and Transport Review 25, October: 34-45.

Association of State Road Transport Undertakings. 2002. The performance of STUs at a glance for the period 1989-90 to 2000-01. Delhi, India: ASRTU. Accessible at: http://www.asrtu.org/data-00-01.PDF.

Association of State Road Transport Undertakings. 2002b. STU policy issue. Delhi, India: ASRTU. Available at: http://www.asrtu.org/stu_policy.htm. Accessed: November 2003.

Bertaud, A. 2002. The economic impact of land and urban planning regulations in India. Unpublished manuscript accessible at: http://www.alain-bertaud.com/ images/AB_\%20India_\%20Urban_Land_Reform.doc.

Brihanmumbai Electric Supply and Transport. Organisational information. Mumbai, India: Available at: http://www.bestundertaking.com/org_info.asp. Accessed: November 2003.

Central Intelligence Agency. 2002. The CIA world fact book. Washington, DC: CIA. Accessible at: http://www.cia.gov/cia/publications/factbook/geos/in.html.

Delhi Metro Rail Corporation Ltd. 2003a. Project update. New Delhi, India: Delhi Metro Rail Corporation. Available at: http://www.delhimetrorail.com/home/ projectUpdate.htm. Accessed: November 2003.

Delhi Metro Rail Corporation 2003b. Cost and funding plan. New Delhi, India: Delhi Metro Rail Corporation. Available at: http://www.delhimetrorail.com/home/ MetroFastFactsCost.htm Accessed: January 2004.

Delhi Metro Rail Corporation Ltd. 2003c. History. New Delhi, India: Delhi Metro Rail Corporation. Available at:http://www.delhimetrorail.com/home/history.htm. Accessed: November 2003.

Gakenheimer, R. 2002. Planning transportation and land use for cities in India. Cambridge, MA: Massachusetts Institute of Technology.

Gakenheimer, R., and C. Zegras. 2003. Travel demand drivers: Mumbai and Chennai, India. Geneva, Switzerland: World Business Council for Sustainable Development. 
Gaur, M. 2003. Delhi to get new busway. In Institute for Transportation and Development Policy. Sustainable Transport e-update. No.1. May-June 2002. Available at: http://www.itdp.org/STe/STe1/index.html\#delhi. Accessed: November 2003.

Indian Railways. 2002. Annual statistical statements, 2001-2002. New Delhi: Indian Railways.

Indian Railways. 2001. Year book 2000-2001. New Delhi: Indian Railways.

Konkan Railway Corporation Ltd. 1999. Sky bus: The urban transport technology for the new millenium. Navi Mumbai, India: The Konkan Railway Corporation Ltd. Available at: http://www.konkanrailway.com/website/ehtm/sky_bus.htm. Accessed: January 2004.

Marwah, B. R., V. K. Sibal, and S. Sawant. 2001. Bus transport in Delhi. In Morris, Sebastian, ed., India Infrastructure Report 2001. New Delhi, India: Oxford University Press.

Metro Railway Kolkata. 2003. Status of ongoing projects. Kolkata, India: Metro Railway Kolkata. Available at: http://business.vsnl.com/metrorly/status.html. Accessed: November 2003.

Ministry of Railways. 2002. Status paper on Indian railways: Issues and options. New

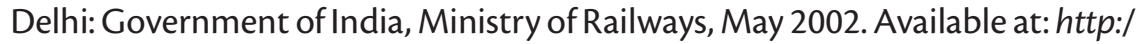
/www.indianrailways.gov.in/railway/status-paper.pdf. Accessed: January 2004.

Ministry of Road Transport and Highways 2003. Motor transport statistics. New Delhi, India. Available at: http://morth.nic.in/mts.htm. Accessed: November 2003.

Ministry of Road Transport and Highways. 1999 and 2000. Handbook on transport statistics in India. Delhi, India: Transport Research Office, Ministry of Road Transport and Highways.

Mumbai Metropolitan Region Development Authority. 2003. Mumbai urban transport project. Mumbai, India: MMRDA. Available at: http:// www.mmrdamumbai.org/mutp2.htm. Accessed: November 2003.

Office of the Registrar General of India. 2001 "Urban agglomerations/cities having population of more than one million in 2001" in The Census of India 2001. New Delhi, India. Available at: http://www.censusindia.net/results/miilion_plus.html. Accessed: November 2003. 
Padam, S., and Singh, S. K. 2001. Urbanization and urban transport in India: The sketch for a policy. Pune, India: Transport Asia Project Workshop. Accessible at: http://www.deas.harvard.edu/TransportAsia/workshop_papers/PadamSingh.pdf.

Pendakur, V. S. 2002. A policy perspective for sustainable cities: Non-motorized transport in Asia. Vancouver, Canada: University of British Columbia.

Ramachandran, R. 1989. Urbanization and urban systems in India. Oxford University Press, Oxford, England.

Southern Railway. 2003. Projects. Chennai, India: Southern Railway. Available at: http://www.southernrailway.org/aboutus/projects.asp. Accessed: November, 2003.

Sreedharan E. 2003. Need for urban mass transport system for our cities. New Delhi, India: Press Information Bureau, Government of India.

Varshneya, Jain, and Sahai. 2002. Strategy for solving transport problems in Mumbai. Mumbai, India: Indian Railways.

Vasconcellos, E. 2001. Urban transport, environment and equity: The case for developing countries. London, UK: Earthscan Press.

World Bank. 2002. India's transport sector: The challenges ahead. Washington, DC: The World Bank.

\section{About the Author}

JoHn PucheR (pucher@rci.rutgers.edu) is professor of urban planning and public policy at Rutgers University in New Brunswick, New Jersey. He specializes in comparative research on transport systems, travel behavior, and public policies in the United States, Canada, and Europe.

NeEnU ItTyerah (neenuittyerah@hotmail.com) is a senior transport manager for the Indian Railways, currently in charge of the freight operations and information system in the Southern and Southwestern Zones. She spent the 2002-03 academic year at Rutgers University as a Humphrey Fellow of the U.S. State Department.

Nisha Korattrswaroopam (nishak@eden.rutgers.edu) is a Ph.D. candidate at Edward J. Bloustein School of Planning and Public Policy, Rutgers University, New Brunswick, New Jersey. Her research interests include urban public transportation and transportation in developing countries. 